\title{
Chewing Lice of Swan Geese (Anser cygnoides): New Host-Parasite Associations
}

\author{
Chang-Yong Choi',2, John Y. Takekawa², Diann J. Prosser ${ }^{3}$ Lacy M. Smith², Craig R. Ely', Anthony D. Fox ${ }^{5}$, \\ Lei $\mathrm{Cao}^{6}$, Xin Wang ${ }^{6}$, Nyambayar Batbayar, Tseveenmayadag Natsagdorj ${ }^{8}$, Xiangming Xiao,* \\ ${ }^{1}$ Department of Microbiology and Plant Biology, University of Oklahoma, Norman, Oklahoma 73019, USA; 2U.S. Geological Survey, Western \\ Ecological Research Center, San Francisco Bay Estuary Field Station, Vallejo, California 94592, USA; '3.S. Geological Survey, Patuxent Wildlife \\ Research Center, Beltsville, Maryland 20705, USA; ${ }^{4}$ U.S. Geological Survey, Alaska Science Center, Anchorage, Alaska 99508, USA; ${ }^{5}$ Department \\ of Bioscience, University of Aarhus, Kalø, Rønde, DK-8410, Denmark; ${ }^{6}$ Department of Environmental Bio-Technology, Chinese Academy of \\ Sciences, Beijing 100085, People's Republic of China; 'Wildlife Science and Conservation Center, Ulaanbaatar 210351, Mongolia; 'Ornithology \\ Laboratory, Institute of Biology, Mongolian Academy of Sciences, Ulaanbaatar 210351, Mongolia
}

\begin{abstract}
Chewing lice (Phthiraptera) that parasitize the globally threatened swan goose Anser cygnoides have been long recognized since the early 19th century, but those records were probably biased towards sampling of captive or domestic geese due to the small population size and limited distribution of its wild hosts. To better understand the lice species parasitizing swan geese that are endemic to East Asia, we collected chewing lice from 14 wild geese caught at 3 lakes in northeastern Mongolia. The lice were morphologically identified as 16 Trinoton anserinum (Fabricius, 1805), 11 Ornithobius domesticus Arnold, 2005, and 1 Anaticola anseris (Linnaeus, 1758). These species are known from other geese and swans, but all of them were new to the swan goose. This result also indicates no overlap in lice species between older records and our findings from wild birds. Thus, ectoparasites collected from domestic or captive animals may provide biased information on the occurrence, prevalence, host selection, and host-ectoparasite interactions from those on wild hosts.
\end{abstract}

Key words: Trinoton anserinum, Ornithobius domesticus, Anaticola anseris, chewing louse, swan goose

Chewing lice (Phthiraptera: Ischnocera and Amblycera), once commonly referred to as paraphyletic Mallophaga, are small dorsoventrally-flattened insects mainly feeding on feathers, skin scales, and secretions of birds and some mammals as permanent ectoparasites [1]. Although their hosts use diverse defenses, such as grooming and preening, bathing, dusting, feather molting, and some chemicals [2], these lice may cause negative effects and welfare issues on wild birds as well as poultry, by increasing feather breakage and associated energetic costs as well as by lowering fitness of wild hosts in terms of survival, reproduction, and sexual selection [3-5]. In addition, they may also serve as vectors or intermediate hosts of other parasites $[1,6,7]$. Although describing the diversity of chewing lice and their host association is an important step for further

• Received 27 November 2015, revised 21 July 2016, accepted 12 August 2016

*Corresponding author (xiangming.xiao@ou.edu)

(c) 2016, Korean Society for Parasitology and Tropical Medicine

This is an Open Access article distributed under the terms of the Creative Commons Attribution Non-Commercial License (http://creativecommons.org/licenses/by-nc/4.0) which permits unrestricted non-commercial use, distribution, and reproduction in any

medium, provided the original work is properly cited. ecological and evolutionary studies [1], the fauna on a variety of wild hosts in many areas remains unstudied.

The swan goose Anser cygnoides (Linnaeus, 1758) is a globally-threatened waterfowl species with a small and rapidly declining wild population [8]. As an endemic goose species to East Asia, it breeds in eastern Russia, Mongolia and northern China and virtually the entire global population winters in the Yangtze floodplain in China [8-10] along with a few sites in Korea. In spite of the limited geographic distribution of its wild population, this goose was domesticated many centuries ago and widely farmed especially in warm climates and at low latitudes [9].

Chewing lice parasitism in swan geese has been recognized as early as the 19th century [11,12], and 3 species have been known on the goose. Price et al. [13] listed Anatoecus icterodes (Nitzsch, 1818) and Anaticola cygnopsis (Rudow, 1869) summarizing previous reports [11,12]. Złotorzycka [14] added Ciconiphilus pectiniventris (Harrison, 1916) collected in a Polish zoo. Two of them are cosmopolitan ectoparasites occurring on diverse waterfowl (C. pectiniventris on geese and swans and 
Anatoecus icterodes on ducks and geese), while A. cygnopsis is assumed to be host specific only to the swan goose [13].

However, our current knowledge about chewing lice on this goose relies on few and outdated observations, including those from the earliest era of chewing louse taxonomy, without any subsequent reports [13]. Here, we aimed to collect new information on the chewing lice parasitizing wild swan geese in East Asia and to update existing knowledge about the host as- sociation of identified chewing lice in this little studied area.

From 27 to 31 July in 2014, we captured 14 swan geese at 3 lakes in northeastern Mongolia (Fig. 1) using standard dipnetting and corral trap techniques during the molting period $[8,15]$. We applied $70 \%$ ethyl alcohol to wet neck feathers for disease surveillance through blood sampling [15], and briefly searched head, neck, and breast of geese for lice running out of the plumage of the alcohol-applied and restrained geese.

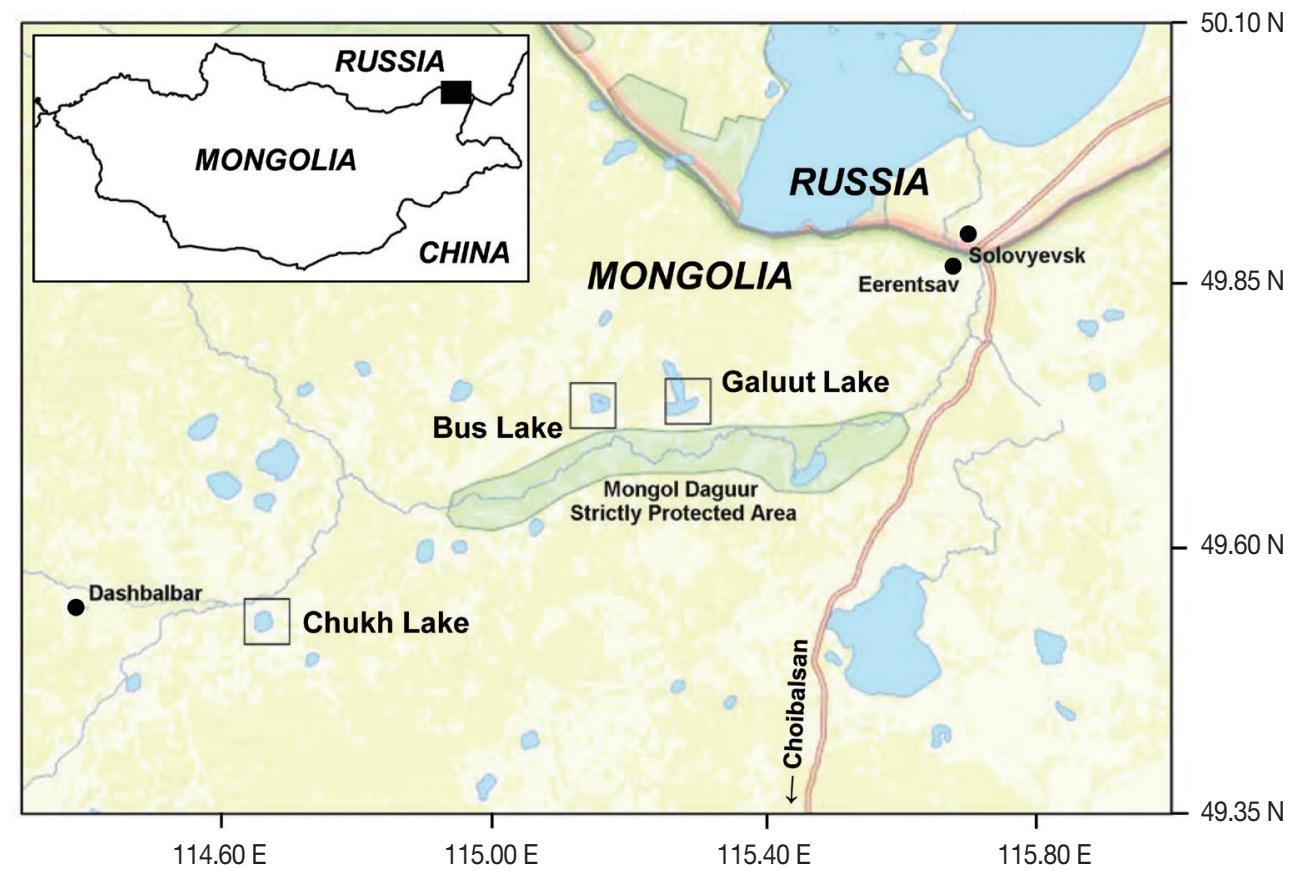

Fig. 1. Location of study sites in northeastern Mongolia where wild swan geese were sampled for parasitic lice in 2014.

Table 1. Chewing lice collected from wild swan geese (Anser cygnoides) in Mongolia (F: female, M: male, N: nymph, U: unknown)

\begin{tabular}{|c|c|c|c|c|c|c|}
\hline \multirow{2}{*}{ Date } & \multirow{2}{*}{ Locality } & \multicolumn{2}{|c|}{ Host } & \multicolumn{3}{|c|}{ Chewing lice } \\
\hline & & Age & Sex & Trinoton anserinum & Ornithobius domesticus & Anaticola anseris \\
\hline 27-Jul-14 & Galuut Lake & Juv & $\mathrm{F}$ & $2 \mathrm{~F}$ & -- & -- \\
\hline 28-Jul-14 & Galuut Lake & Juv & $\mathrm{F}$ & $1 F$ & -- & -- \\
\hline 29-Jul-14 & Bus Lake & Juv & $\mathrm{F}$ & $1 \mathrm{M}$ & -- & -- \\
\hline 29-Jul-14 & Bus Lake & Juv & $\mathrm{F}$ & $1 F$ & -- & -- \\
\hline 29-Jul-14 & Bus Lake & Juv & $\mathrm{F}$ & $1 F$ & -- & -- \\
\hline 29-Jul-14 & Bus Lake & Juv & M & -- & $1 F$ & -- \\
\hline 29-Jul-14 & Bus Lake & Adult & $\mathrm{F}$ & $3 \mathrm{M}, 1 \mathrm{~F}, 2 \mathrm{~N}$ & -- & -- \\
\hline 31-Jul-14 & Chukh Lake & Juv & M & $1 \mathrm{M}$ & $2 F$ & -- \\
\hline 31-Jul-14 & Chukh Lake & Juv & $\mathrm{F}$ & -- & $1 \mathrm{M}$ & -- \\
\hline 31-Jul-14 & Chukh Lake & Juv & M & $1 \mathrm{M}$ & -- & -- \\
\hline 31-Jul-14 & Chukh Lake & Juv & M & $1 \mathrm{M}, 1 \mathrm{~F}$ & $3 \mathrm{~F}, 1 \mathrm{~N}$ & $1 \mathrm{~F}$ \\
\hline 31-Jul-14 & Chukh Lake & $U$ & $U$ & -- & $1 \mathrm{M}$ & -- \\
\hline 31-Jul-14 & Chukh Lake & $U$ & U & -- & $1 \mathrm{~N}$ & -- \\
\hline 31-Jul-14 & Chukh Lake & U & U & -- & $1 F$ & -- \\
\hline Total & & & & $16(7 \mathrm{M}, 7 \mathrm{~F}, 2 \mathrm{~N})$ & $11(2 \mathrm{M}, 7 \mathrm{~F}, 2 \mathrm{~N})$ & $1(1 F)$ \\
\hline
\end{tabular}


We collected a few first-observed lice in a non-quantitative manner, to minimize the stress caused by long handling times and blood sampling, and stored the lice in 70\% alcohol. Procedures for this field research were approved by Institutional Animal Care and Use Committee of the University of Oklahoma (R12-004) and USGS Patuxent Wildlife Research Center (2007-01). Given the lack of comparative samples for molecular species identification, the collected lice were identified later to the species level using available taxonomic keys and mor- phological descriptions [13,14,16-26].

A total of 28 chewing lice comprised of 3 different species were collected from all examined individuals in northeastern Mongolia (Table 1; Fig. 2): 16 Trinoton anserinum (Fabricius, 1805) consisting of 7 males, 7 females, and 2 nymphs from 9 birds at 3 lakes, 11 Ornithobius domesticus Arnold, 2005 including 2 males, 7 females, and 2 nymphs from 7 geese at 2 lakes, and a single female Anaticola anseris (Linnaeus, 1758) from 1 juvenile goose at 1 lake (Table 1). All of these 3 species were
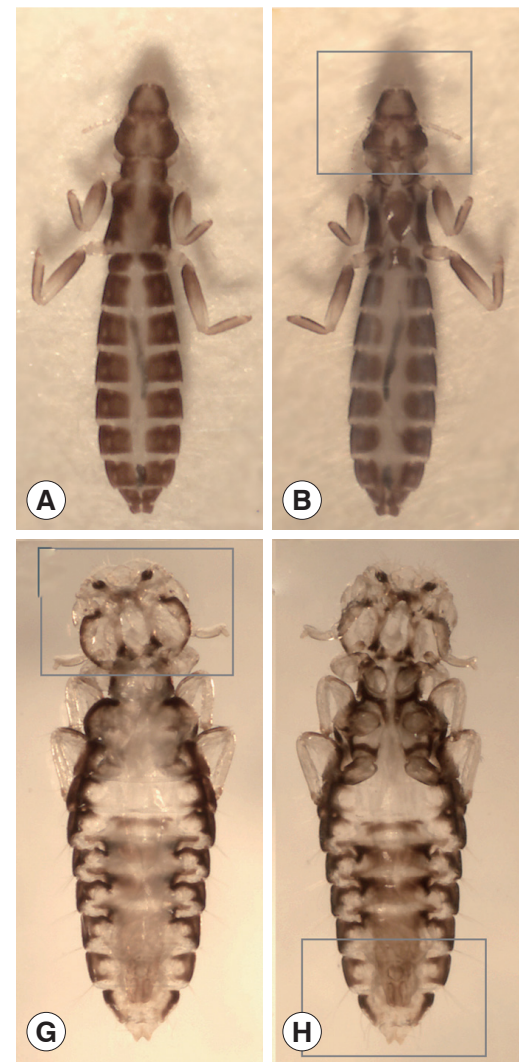
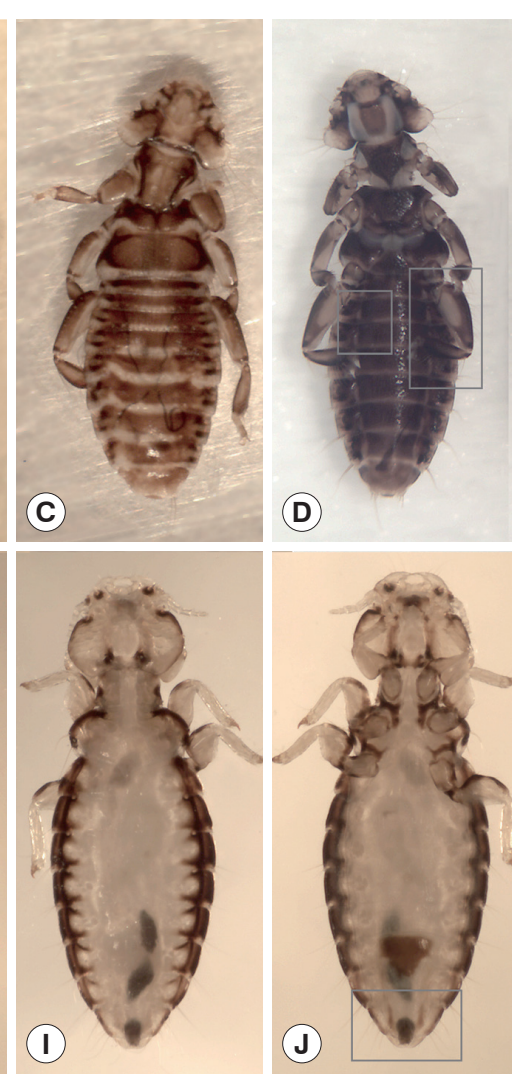
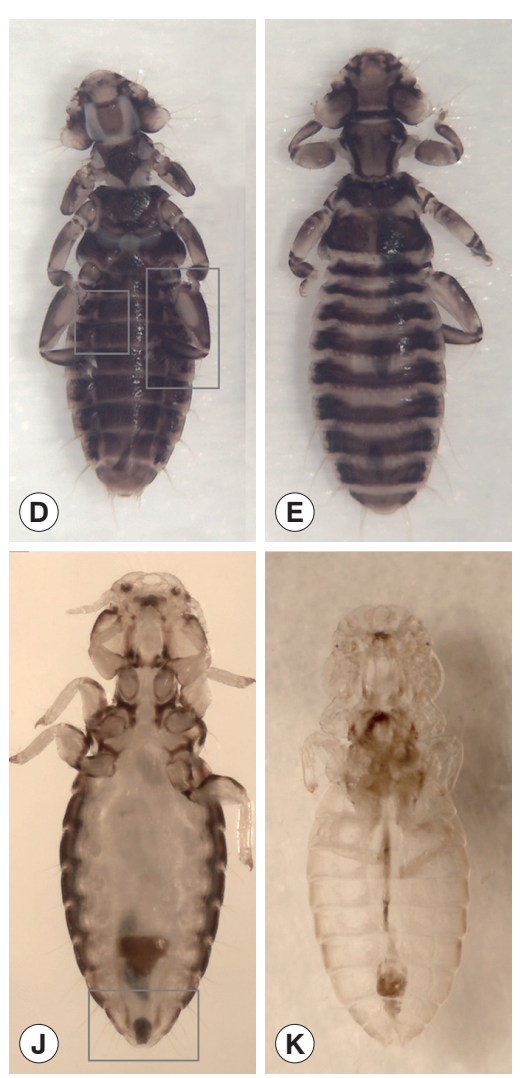

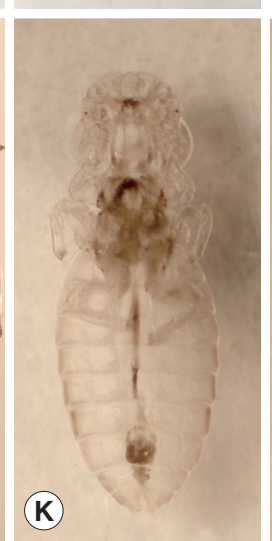

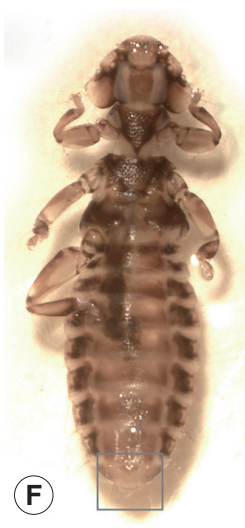

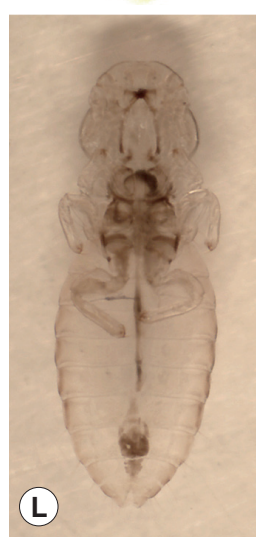

Fig. 2. Chewing lice collected from wild swan geese (Anser cygnoides) in Mongolia. Female Anaticola anseris (A: dorsal, B: ventral); male (C: dorsal, D: ventral) and female (E: dorsal, F: ventral) of Trinoton anserinum; male (G: dorsal, H: ventral), female (l: dorsal, J: ventral), and nymph (K: dorsal, L: ventral) of Ornithobius domesticus. Grey open boxes represent the body parts of enlarged plates in Fig. 3. Not to scale (refer to Table 3 for measurements).

Table 2. List of chewing lice reported from the swan geese (Anser cygnoides)

\begin{tabular}{|c|c|c|}
\hline Chewing lice & Origin of host & Source \\
\hline \multicolumn{3}{|l|}{ Philopteridae (Phthiraptera: Ischnocera) } \\
\hline Anaticola anseris (Linnaeus, 1758) & Wild population & This study \\
\hline Anatoecus icterodes (Nitzsch, 1818) & Unknown (possibly domestic or captive goose) & {$[12]$} \\
\hline Ornithobius domesticus Arnold, 2005 & Wild population & This study \\
\hline \multicolumn{3}{|l|}{ Menopodidae (Phthiraptera: Amblycera) } \\
\hline Trinoton anserinum (Fabricius, 1805) & Wild population & This study \\
\hline
\end{tabular}


new to the swan goose, resulting in a total of 6 chewing lice species in 2 parasitic families and suborders: Philopteridae (Ischnocera) and Menopodidae (Amblycera) (Table 2).

Unlike many other host-specific Anaticola lice in Philopteridae, A. anseris found in this study (Fig. 2A, B) is 1 of 3 exceptions having multiple closely related hosts of goose species belonging to the genera Anser and Branta [13,26]. A. anseris is morphologically similar to A. crassicornis mainly occurring in ducks of the genus Anas, but can be identified by some morphological characteristics such as bigger body size, chetotaxy at the anterior region of the head, setae in the subgenital plate of females, and long and blunt penis in the male genitalia $[20,22,26]$. One of the ventral anterior head setae appears strongly thickened in A. crassicornis (total length: 3.1-3.3 mm in males, 3.6$3.7 \mathrm{~mm}$ in females [26]), but our single female (3.95 $\mathrm{mm}$ in total length; Table 3) has long, equal, and relatively thin ventral setae (Fig. 3A) and a pair of long dorsal setae reaching mandibles [26] at the anterior region of the head, showing the key morphological features of the female A. anseris.

T. anserinum in Menopodidae is a large louse (5.3-6.3 mm in length [22]) typically occurring on geese and swans [13,22].
Many morphological features, such as stout spine-like setae on their gular, dorsal hind head, and dorsal prothorax, are shared by $T$. querquedulae which mainly occurs in ducks $[16,18,22], T$. querquedulae is smaller in size (4.3-5.8 $\mathrm{mm}$ in length [22]) and it has fewer setae in prosternum, smaller brush patches of fewer hairs around short spine-shaped setae on sternites IV and V, and a smaller thickening in the dorsal wall of the female genital chamber than T. anserinum $[16,18,22]$. Our samples (Fig. 2C-F) were 5.3-6.4 $\mathrm{mm}$ in total length (Table 3) and showed numerous fine hairs forming relatively large patches on their sternites IV and V contrasting with adjacent long and thick setae (Fig. 3B) as well as on the third femora (Fig. 3C) unlike other groups, such as the T. aculeatum group and the most similar T. querquedulae group, that have fewer, thicker, and longer hairs in smaller or no patches on the sternites IV and V $[16,18,22]$. We also confirmed that the posterior tip of the thickened dorsal wall of genital chamber is elongated and pointed in females (Fig. 3D) that is an important diagnostic key for T. anserinum [18]. Eight samples were provided to the Illinois Natural History Survey at University of Illinois, USA for possible molecular analysis, and we deposited 4 and 3 to

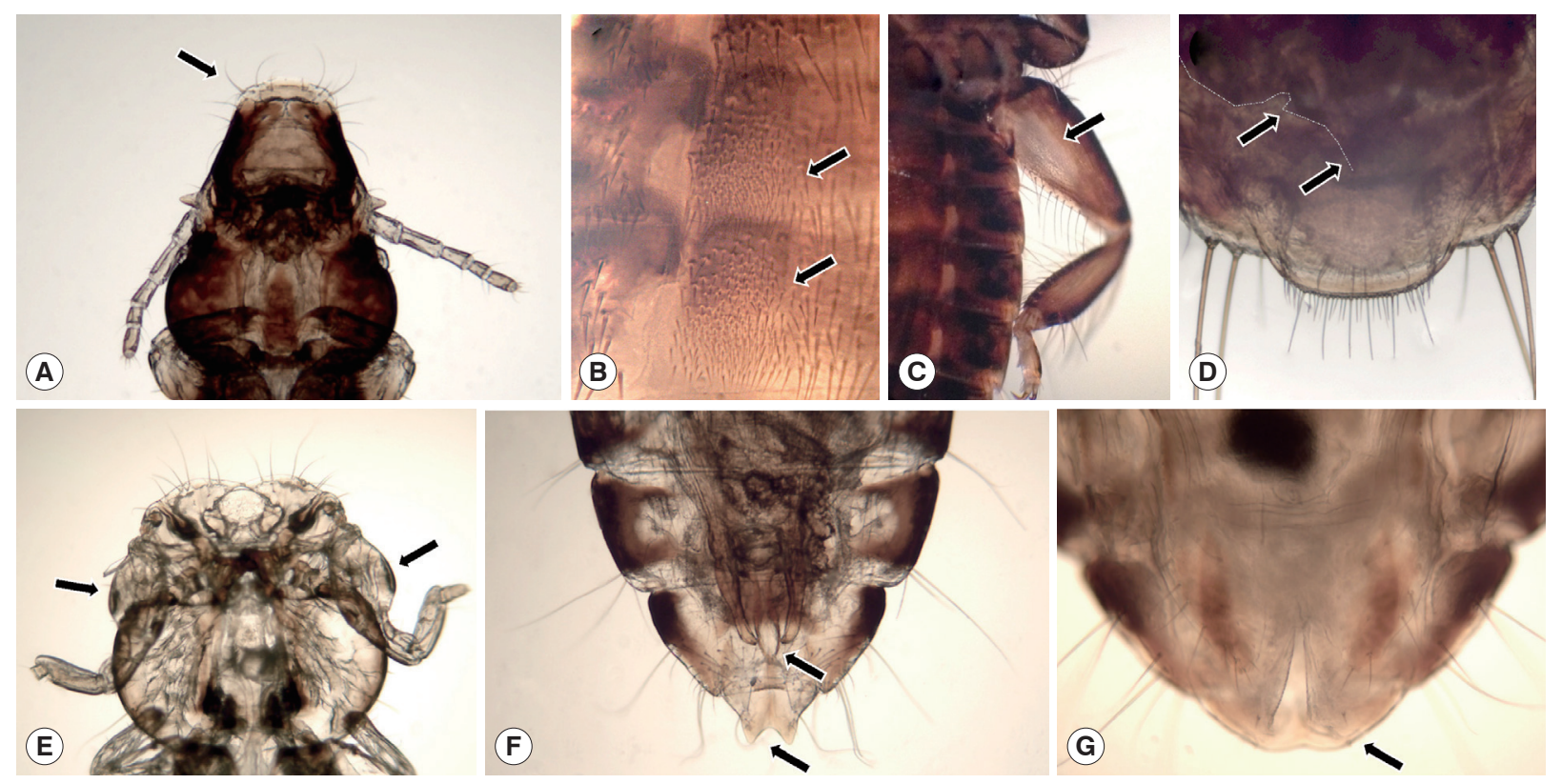

Fig. 3. Body parts of 3 lice species collected from wild swan geese (Anser cygnoides) in Mongolia. Ventral view of (A) the head of a female Anaticola anseris having equally long and relatively thin setae on its anterior head. Brush patches (B) on sternites IV and $V$ and (C) on the ventral side of the 3rd femora in a male Trinoton anserinum. Ventral view of (D) terminalia of a female T. anserinum showing a posterior part of a dark thickening in the dorsal wall of the female genital chamber; the left rear edge of the symmetric thickening was marked grey for reference. Dorsal view of $(E)$ the head of a male Ornithobius domesticus with strongly enlarged and bulky antenna scapes. Ventral terminalia of $O$. domesticus showing ( $F$ ) the deep-forked tip and the elongated mesosome of its genitalia in a male and (G) the slightly concaved terminal segment in a female. 
the National Institute of Biological Resources (NIBR) and the Parasite Resource Bank at Chungbuk National University, respectively, in South Korea.

Lice in the genus Ornithobius belonging to Philopteridae are found on geese and swans of the genera Anser, Branta, and Cyngus [23], and especially O. domesticus was reported only on swans (unknown Cygnus species) in Shanghai, China [23]. The type specimens of this species were collected from domestic or captive swans in 1939, but the collection site is located in the Yangtze River watershed, the main wintering range of swan geese in southern China, suggesting that $O$. domesticus may occur on wild geese and swans in East Asia as well as on domesticated hosts in China. This species, ranging from 3.8-4.6 mm in size (Fig. 2G-L; Table 3), can be distinctively separated from all other Ornithobius species by strongly enlarged antennae (Fig. 3E) [23], the elongated tongue-shaped mesosome of the male genitalia (Fig. 3F) [23], and the distinctly forked terminal segment of abdomens (Fig. 3F), while other Ornithobius species have rounded or pointed terminal segments in males [16, 24,25]. Females have unique abdominal color patterns with short horizontal stripes (Fig. 2I, J) and slightly concaved terminalia (Fig. 3G). In particular, a small Head-Index (length/ width of head [24]) of 0.92 (range: 0.85-0.99) was derived from our measurements (Table 3). This result represents their laterally-flattened, oval-shaped heads contrasting to rounded or elongated heads in other Ornithobius species (Head-Index of 1.00-1.18) [16,23-25]. We deposited 3 samples (male, fe- male, and nymph) in NIBR.

All 3 of these species are typical ectoparasites to large waterfowl such as geese and swans [13,22-26]. Eichler and Vasjukova $[20,21]$ described that domestic geese infested by T. anserinum and A. anseris experienced strongly degraded feather conditions. Furthermore, T. anserinum is known to transmit a common heartworm to swans and geese as an obligate ectoparasite $[6,7]$. Although we could not see any evidence of severe infestation or symptoms of associated illness, potential pathogenicity and impacts of the infestation of these 3 lice to the swan goose are still unknown, and it may be addressed in follow-up studies for the welfare and conservation of this threatened species.

Chewing lice parasitism of swan geese has been long recognized by Rudow [11] and Giebel [12]. However, we did not find the chewing lice species reported in previous studies, documenting a total of 6 lice species on the swan goose (Table 2). Because geese of the genus Anser are known hosts of previously reported A. icterodes and C. pectiniventris [13], these may occur in wild populations of the swan goose despite lack of detection during our brief inspection. A. cygnopsis is believed to be a host-specific louse occurring only on the swan goose [13], but the lack of occurrence in our samples indicates that A. cygnopsis is not a highly prevalent louse, at least, amongst wild swan geese, as previously noted [27]. However, more importantly, we suggest that the previous information on chewing lice on the swan goose may be biased towards sampling of

Table 3. Morphometrics of chewing lice collected from wild swan geese (Anser cygnoides) in Mongolia

\begin{tabular}{|c|c|c|c|c|c|c|c|}
\hline \multirow{2}{*}{ Measured part } & \multicolumn{3}{|c|}{ Trinoton anserinum } & \multicolumn{3}{|c|}{ Ornithobius domesticus } & \multirow{2}{*}{$\frac{\text { Anaticola anseris }}{\text { Female }(n=1)}$} \\
\hline & Male $(n=3)$ & Female $(n=1)$ & Nymph $(n=2)$ & Male $(n=2)$ & Female $(n=6)$ & Nymph $(n=2)$ & \\
\hline Head length in midline (HL) & $\begin{array}{c}0.92 \\
(0.89-0.95)\end{array}$ & 0.90 & $\begin{array}{c}0.53 \\
(0.52-0.53)\end{array}$ & $\begin{array}{c}0.95 \\
(0.86-1.03)\end{array}$ & $\begin{array}{c}0.94 \\
(0.89-0.99)\end{array}$ & $\begin{array}{c}0.76 \\
(0.71-0.81)\end{array}$ & 0.67 \\
\hline Head width at temple (HW) & $\begin{array}{c}1.44 \\
(1.36-1.55)\end{array}$ & 1.53 & $\begin{array}{c}0.79 \\
(0.78-0.79)\end{array}$ & $\begin{array}{c}1.03 \\
(1.01-1.04)\end{array}$ & $\begin{array}{c}1.02 \\
(0.93-1.06)\end{array}$ & $\begin{array}{c}0.9 \\
(0.89-0.90)\end{array}$ & 0.59 \\
\hline Thorax length (LT) & $\begin{array}{c}1.72 \\
(1.65-1.77)\end{array}$ & 1.85 & $\begin{array}{c}0.70 \\
(0.69-0.71)\end{array}$ & $\begin{array}{c}0.97 \\
(0.93-1.01)\end{array}$ & $\begin{array}{c}0.89 \\
(0.84-0.97)\end{array}$ & $\begin{array}{c}0.64 \\
(0.57-0.71)\end{array}$ & 0.89 \\
\hline Prothorax width (PW) & $\begin{array}{c}1.09 \\
(1.05-1.14)\end{array}$ & 1.20 & $\begin{array}{c}0.57 \\
(0.54-0.59)\end{array}$ & $\begin{array}{c}0.63 \\
(0.62-0.63)\end{array}$ & $\begin{array}{c}0.59 \\
(0.55-0.62)\end{array}$ & $\begin{array}{c}0.51 \\
(0.49-0.52)\end{array}$ & 0.42 \\
\hline Metathorax width (MW) & $\begin{array}{c}1.57 \\
(1.52-1.63)\end{array}$ & 1.60 & $\begin{array}{c}0.73 \\
(0.69-0.76)\end{array}$ & $\begin{array}{c}1.02 \\
(0.99-1.05)\end{array}$ & $\begin{array}{c}1.03 \\
(0.91-1.07)\end{array}$ & $\begin{array}{c}0.81 \\
(0.79-0.83)\end{array}$ & 0.61 \\
\hline Abdominal length in midline (AL) & $\begin{array}{c}2.84 \\
(2.73-2.91)\end{array}$ & 3.62 & $\begin{array}{c}0.94 \\
(0.65-1.23)\end{array}$ & $\begin{array}{c}2.52 \\
(2.41-2.63)\end{array}$ & $\begin{array}{c}2.32 \\
(2.06-2.42)\end{array}$ & $\begin{array}{c}1.80 \\
(1.76-1.84)\end{array}$ & 2.39 \\
\hline Abdomen width (AW) & $\begin{array}{c}1.78 \\
(1.73-1.86)\end{array}$ & 1.86 & $\begin{array}{c}0.72 \\
(0.62-0.82)\end{array}$ & $\begin{array}{c}1.39 \\
(1.34-1.44)\end{array}$ & $\begin{array}{c}1.45 \\
(1.26-1.55)\end{array}$ & $\begin{array}{c}1.15 \\
(1.09-1.21)\end{array}$ & 0.81 \\
\hline Total length (TL) & $\begin{array}{c}5.47 \\
(5.29-5.63)\end{array}$ & 6.37 & $\begin{array}{c}2.17 \\
(1.89-2.44)\end{array}$ & $\begin{array}{c}4.38 \\
(4.41-4.64)\end{array}$ & $\begin{array}{c}4.11 \\
(3.76-4.25)\end{array}$ & $\begin{array}{c}3.16 \\
(3.01-3.31)\end{array}$ & 3.95 \\
\hline
\end{tabular}

Measurements are given as mean values in millimeters with the ranges in parentheses. 
captive or domestic geese. Of the current records, C. pectiniventris was found on a captive swan goose as a probable straggler from other associated but unknown captive hosts in a zoo [14], and A. cygnopsis was first described on a goose from the 'East Indies' [11], far beyond the natural distribution of the swan goose [8-10].

A. icterodes was originally described from the goose as Docophorus brunneiceps [12], but any detailed information on its host and locality was not described, raising a reasonable doubt that its host was a wild goose. Our suggestion is largely supported by the great abundance and worldwide distribution of domesticated forms of the swan goose, in contrast to the small, wild population (60,000-80,000 birds) and its restricted and remote geographic distribution $[8,9]$. After the recent spread of highly pathogenic avian influenza in wild waterfowl, surveillance of the heath condition and diseases of wild geese has been emphasized and conducted in East Asia [28]. Nevertheless, to our best of knowledge, no previous survey has been conducted to document the host-chewing lice association in wild swan geese populations. Therefore, we believe that our findings provide the first data on the chewing lice and host association confirmed from the true wild swan goose.

In conclusion, the lack of overlap between previous studies and our preliminary findings suggests that ectoparasites collected from domestic or captive animals may provide biased information on the occurrence, prevalence, host selection, and host-ectoparasite interactions from those in wild populations of the same host. Therefore, as a first step in understanding diversity, ecology, and evolution of chewing lice and their associated hosts, surveillance sampling should be taken into accounts on the nature and ecology of wild hosts. Close cooperation among field biologists, parasitologists, and entomologists based on extensive and systematic collection efforts and phylogenetic studies will benefit these efforts. Furthermore, it is also recommended to examine the validity of the A. cygnopsis that has poor descriptions for a future work, because authenticated material from the type host was never found after the original collection in the 19th century [27]

\section{ACKNOWLEDGMENTS}

We appreciate assistance of the staff of the Wildlife Science and Conservation Center of Mongolia, Korea Institute of Environmental Ecology, and Korean Ministry of Agriculture, Food, and Rural Affairs during the field study. This work was led by the U.S. Geological Survey Western Ecological Research Center and University of Oklahoma, and supported by grants from the National Institutes of Health (1R56TW009502-01), National Institute of Allergy and Infectious Diseases (1R01AI10102801AI), and U.S. Geological Survey (A14-0064), USA.

\section{CONFLICT OF INTEREST}

We declare that there is no conflict of interests in this study.

\section{REFERENCES}

1. Johnson JP, Clayton DH. The biology, ecology, and evolution of chewing lice. In Price RD, Hellenthal RA, Palma RL, Johnson KP, Clayton DH eds, The Chewing Lice: World Checklist and Biological Overview. Springfield, Illinois, USA. Illinois Natural History Survey. 2003, pp 449-476.

2. Clayton DH, Koop JAH, Harbison CW, Moyer BR, Bush SE. How birds combat ectoparasites. Open Ornithol J 2010; 3: 41-71.

3. Booth DT, Clayton DH, Block BA. Experimental demonstration of the energetic cost of parasitism in free-ranging hosts. Proc $\mathrm{R}$ Soc Lond B 1993; 253: 125-129.

4. Kose M, Møller AP. Sexual selection, feather breakage and parasites: the importance of white spots in the tail of the barn swallow (Hirundo rustica). Behav Ecol Sociobiol 1999; 45: 430-436.

5. Moreno-Rueda G, Hoi H. Female house sparrows prefer big males with a large white wing bar and fewer feather holes caused by chewing lice. Behav Ecol 2012; 23: 271-277.

6. Seegar WS, Schiller EL, Sladen WJL, Trpis M. A mallophaga, Trinoton anserium, as a cyclodevelopmental vector for a heartworm parasite of waterfowl. Science 1976; 194: 739-741.

7. Cohen S, Greenwood MT, Fowler JA. The louse Trinoton anserium (Amblycera: Phthiraptera); an intermediate host of Sarconema eurycerca (Filarioidea: Nematoda), a heartworm of swans. Med Veter Entomol 1991; 5: 101-110.

8. Batbayar N, Takekawa JY, Newman SH, Prosser DJ, Natsagdorj T, Xiao X. Migration strategies of swan geese Anser cygnoides from northeast Mongolia. Wildfowl 2011; 61: 90-109.

9. Kear J. Ducks, Geese, and Swans. Volume 1: General Chapters, and Species Accounts (Anhima to Salvadorina). New York, USA. Oxford University Press. 2005, pp 263-266.

10. Zhang Y, Cao L, Barter M, Fox AD, Zhao M, Meng F, Shi H, Jiang $\mathrm{Y}$, Zhu W. Changing distribution and abundance of swan goose Anser cygnoides in the Yangtze River floodplain: the likely loss of a very important wintering site. Bird Conserv Int 2011; 21: 36-48.

11. Rudow F. Beitrag zur Kenntniss der Mallophagen oder Pelzfresser. Neue exotische Arten der Familie Philopterus. Leipzig, Germany. Universitat Leipzig. 1869, pp 37-38.

12. Giebel CG. Insecta Epizoa. Leipzig, Germany. Otto Wignad. 1874, p 308.

13. Price RD, Hellenthal RA, Palma RL. World checklist of chewing 
lice with host associations and keys to families and genera. In Price RD, Hellenthal RA, Palma RL, Johnson KP, Clayton DH eds, The Chewing Lice: World Checklist and Biological Overview. Springfield, Illinois, USA. Illinois Natural History Survey. 2003, pp 1-448.

14. Złotorzycka J. Wszoly - Mallophaga: Nadrodzina Menoponoidea. Polskie Towarzystwo Entomologiczne [Klucze do Oznaczania Owadów Polski] 1976; 15: 1-189.

15. Whitworth D, Newman SH, Mundkur T, Harris P. Wild Birds and Avian Influenza: an Introduction to Applied Field Research and Disease Sampling Techniques. Rome, Italy. Food and Agriculture Organization of the United Nations. 2007, pp 33-84.

16. Clay T, Hopkins GHE. The early literature on Mallophaga: Part I. Bull Br Mus (Nat Hist) Entomol 1950; 1: 221-272.

17. Clay T, Hopkins GHE. The early literature on Mallophaga: Part II. Bull Br Mus (Nat Hist) Entomol 1951; 2: 1-36.

18. Clay T, Hopkins GHE. The early literature on Mallophaga: Part IV. Bull Br Mus (Nat Hist) Entomol 1960; 9: 1-61.

19. Clay T. A key to the genera of the Menoponidae (Amblycera: Mallophaga: Insecta). Bull Br Mus (Nat Hist) Entomol 1969; 24 : $1-26$.

20. Eichler W, Vasjukova TT. Die Mallophagengattung Anaticola (Phthiraptera, Mallophaga). Dtsch Ent Z (NF) 1980; 27: 335375.

21. Eichler W, Vasjukova TT. Die Mallophagengattung Trinoton. Mitt
Zool Mus Berlin 1981; 57: 23-62.

22. Castresana L, Totario A, Mateo PM. Study of the ectoparasitic mallophaga of Anatidae (Insecta, Mallophaga) in the Iberian Peninsula: identification, biometric characteristics and biological aspects. Zool Baetica 1999; 10: 63-86.

23. Arnold DC. Review of the genus Ornithobius (Phthiraptera: Ischnocera: Philopteridae), with descriptions of two new species. J Kans Entomol Soc 2005; 78: 158-166.

24. Balát F. Ornithobius matthewsi: Eine neue Mallophagenart der Graugans, Anser anser L. Annot Zool Bot 1974; 94: 1-6.

25. Timmermann G. Gruppen-Revisionen bei Mallophagen. V. Zur naheren Kennzeichnung des Ornithobius-komplexes (Philopteridae), parasitisch bei Entenvögeln. Z Parasitenkd 1962; 22: 133147.

26. Naz S, Rizvi SA, Sychra O. Anaticola crassicornis (Phthiraptera: Ischnocera: Philopteridae) on wild geese from Pakistan. Zootaxa 2010; 2659: 60-66.

27. Clay T, Hopkins GHE. Notes on the Rudow collection of Mallophaga at Hamburg. Mitt Hamburg Zool Mus Inst 1955; 53: 49-73.

28. Takekawa JY, Prosser DJ, Newman SH, Muzaffar SB, Hill NJ, Yan B, Xiao X, Lei F, Li T, Schwarzbach SE, Howell JA. Victims and vectors: highly pathogenic avian influenza H5N1 and the ecology of wild birds. Avian Biol Res 2010; 3: 1-23. 
